\title{
5 Creating more equal partnerships: Home Economics education and gender equality in Japan and Norway
}

\author{
Jennifer Branlat and Junko Sano
}

Over the years, Home Economics in Japan and Norway has developed along different trajectories but with the shared goal of opening the subject to co-educational participation. In Japan, the subject became a requirement for all students in 1994. In recent years, it has attempted to lead more men towards active participation in home life by keeping domestic and family issues on the curriculum. Norway made Home Economics classes coeducational in 1959 during a period of educational reform for gender equality. However, as the other Scandinavian countries, it has over the past decades opted to narrow its focus to 'food and health' in order to meet health-related social challenges that have supposedly become more urgent than the matter of gender equality.

Home Economics has in the past played an important role in establishing gender equality in the private sphere by educating both men and women towards domestic competence. More recently, as many countries come to promote novel forms of sustainability education, which lies at the intersection of gender equality and environmentally friendly ways of living, we see Home Economics as having a valuable role to play. Equal levels of household competence may reduce the double burden on women and support both partners in the establishment of more sustainable households. Our focus here will be Japan and Norway. In comparing these two different national frameworks, we ask: When it comes to Home Economics education, what are the key differences and similarities between the Japanese and Norwegian national contexts? What can educators and educational leaders from Norway and Japan learn from each other in order to secure a more promising future for the subject?

This chapter begins by briefly reviewing the history of Home Economics education to provide one possible explanation for the subject's diminished status in Norwegian and Japanese education. Home Economics has gone from being a subject for girls only to one which provides each individual, both boys and girls, with the skills to become independent and able to function in a gender-equal society. In the Norwegian context, we draw attention to what might be called a 'post gender equality' attitude that marks a shift in thinking about the rightful place for children and young

DOI: $10.4324 / 9781003185222-5$ 
adults to learn to perform domestic tasks and duties associated with family life. We go on to examine the current position, goals and challenges of today's Home Economics education in both countries, complementing statistics with the qualitative interviews we carried out with educators in lower secondary school and teacher training. The choice to include their perspectives in this chapter was motivated by a desire to show that although gender equality remains an important goal for family and equality policy, Home Economics teachers lack the resources - primarily due to the subject's negative associations with 'women's work' - to meaningfully support this societal aim.

Today, the Scandinavian welfare state is represented internationally as a 'model' for promoting work-life balance based on the dual-earner/dualcarer family model (Cousins \& Tang, 2004; Ellingsæter, 2009). One of the most widely documented effects of this model has been that employment rates for mothers of young children remain among the highest in Europe. If we dig deeper, however, we obtain a more fine-grained understanding of the division of household labour as it pertains to the same group. Kitterød and Rønsen (2012, p. 671) have shown that the equal sharing of paid work, which concerns only $40 \%$ of Norwegian women, is much more common than non-traditional arrangements whereby a woman would work more than her partner ( $10 \%$ of women). Even if the gap between the total time spent by men and women on household tasks and childcare has been greatly reduced since the 1970s, women with young children still spend approximately twice as much time on household tasks and childcare than men. This unequal sharing of household tasks creates a double burden situation whereby women have the responsibility for paid work in the labour market as well as an unequal share of unpaid work in the household. Household work duties are also highly segregated by gender in Norway, as is the case for many other countries (Hook, 2010). Drawing on various studies, Seierstad and Kirton (2015) have contended that 'the domestic division of labour in Norway seems more impervious to state policy measures' than other arenas (p. 394).

In Japan, the Cabinet Office's 2019 survey of about 8000 men and women examined the division of housework and showed that among couples without children, women spent 2.6 times as much time on housework as men in households with couples. When it comes to households with children, women spent from 2.8 to 3.6 times as much time on housework as men and 2.1 to 2.7 times as much time on childcare (Gender Equality Bureau, Cabinet Office, Government of Japan 2020). Even though men's time spent on housework has increased gradually over the past decade in Japan, women still bear most of the burden of household work.

In the light of this current situation for both Japan and Norway, we would like to reflect upon the purpose and relevance of current Home Economics education by asking: Does the subject have the potential to contribute to a more equal distribution of domestic responsibilities? In 


\section{Jennifer Branlat and Junko Sano}

which ways does Home Economics education in its current (as of 2020) form in Japan and Norway support the creation of a more gender-equal society? In regards to the latter, we refer to the United Nations' Sustainable Development Goals (SDGs), the fifth of which targets 'the promotion of shared responsibility within the household and the family as nationally appropriate' (United Nations General Assembly, 2015). If Home Economics education in Norway and Japan continues facing significant challenges - such as meagre budgets for classroom learning activities, low ranking within the 'the traditional curriculum hierarchy' (Bleazby, 2015, p. 261), the constant reduction of required study hours and relatively few male teachers - how will it be able to contribute to gender equality?

\section{Home Economics, modernisation and the legitimisation of women's education}

It is important to note that the history of Home Economics education in Japan, as in Norway, is closely related to the history of traditional women's work (Øvrebø \& Engeset, 2020; Makino, 2005). Even prior to the modernisation of Japan in 1868 and the subsequent creation of the national education system in 1872, women were responsible for weaving and sewing fabric for underwear and bedding, as well as clothing for their families. Sewing, considered to be a distinctly women's art, endures even today as a part of the Home Economics curriculum. In Japan, during the late 1930s as part of the war effort, Home Economics was doubled in number of hours, and classes were dedicated to the production of supplies in support of the nation. The subject also contributed in pedagogical terms to the emergence of the 'good wife, wise mother' ideology whereby women performed citizenship through raising and educating children while men became part of the national community by engaging in production activities or military duties (Koyama, 2014, p. 97).

In the Norwegian public school system, Home Economics education has undergone many changes since its initial adoption into school curriculum in 1908, but the subject traces its roots back even earlier to 1865 and the creation of the first 'housewife school' ('husmorskole'). Such schools, which arose alongside agricultural schools and where women obtained specialised instruction in domestic subjects, were part of the modernisation of Norway. From its very beginnings in a rural context, the question of healthy eating habits has always occupied a central position (Øvrebø \& Engeset, 2020, p. 11). The increasing number of housewife schools from the mid-19th century onward reflects the state's objective to both formalise and professionalise knowledge (Larsen \& Hagemann, 2011, p. 267) with respect to the home - an initiative that was reinforced by the schools' connections to developments in nutritional science and the natural sciences, particularly microbiology. This initiative gave women a new standing in the family and society, even as it marginalised them. The schools were also instrumental in 
the development of the 'housewife ideology' in Norway, which aimed to 'strengthen the position of the housewife in modern society' and delineate the nature of suitable work for women (Melby, 1989, p. 184). In particular, the Statens loererinneskole for husstell (The State Teacher Training School for Housekeeping), created in 1909 in the city of Stabekk, became what Larsen and Hagemann (2011, p. 268) called a 'hub' for the development of housekeeping as an academic subject, making great strides towards expanding housekeeping outside the home and pushing towards its recognition as a science. The creation of the school in Stabekk, with its attendant networks of public and private actors, also significantly marked 'a cohesive attempt to define housework as something more than just housework. It was about knowledge, work, identity and consumption' [emphasis in original] (Larsen \& Hagemann, 2011, p. 268).

The school reform of 1959, which led to the creation of the mandatory nine-year school (niårig skole), aimed to erase disparities between urban and rural areas and offer equal opportunities to all pupils. This reform secured gender equality a prominent place in the post-war modernisation of Norway. The act also had implications both for Home Economics as an emerging science and for the development of gender equality among pupils. On the one hand, one can see the first manifestations of legal-based gender equality reform in the Norwegian public school system in that all curricular differences between girls and boys were abolished, leading to the elimination of reduced hours in theoretical subjects for girls. Until that time, a gender-divided curriculum stipulated that boys be offered more hours in math and sports, and while girls were offered courses in sewing and domestic arts, boys learned carpentry and crafts. From 1959 onwards, both home knowledge and handcrafts became obligatory subjects for all children. The school reform of 1959, with aims toward gender equality, ironically marked the end of the traditional women's higher education institutions. This was particularly the case for the aforementioned activity clustered around the Statens loererinneskole for husstell, which was, along with other women's-only institutions, transformed into a co-educational teaching college (Larsen \& Hagemann, 2011). Considered in this light, it emerges that initial efforts to create gender-equal conditions in schools were also responsible for dismantling a pillar of women's knowledge, food and nutrition science, which connected women to the more prestigious natural sciences, like microbiology.

As for post-war Japan, in 1968 the field changed dramatically when junior high school 'Vocational and Home Economics' became 'Technology and Home Economics,' and the Ministry of Education divided the subject content along gendered lines with designated content reserved for boys and girls. This change is reflected in how, throughout the 1960s, Japanese corporations strategized to get more workers skilled in STEM by pressing the government to use education to build a skilled workforce. As a result, girls were offered cooking, clothing production, home mechanics/home 


\section{Jennifer Branlat and Junko Sano}

crafts, design/drawing and childcare, while boys' instruction included wood and metal working, design and drafting, electricity and mechanics. This emphasis reflects the fact that Japan's rapid economic growth was dependent on the government's promotion of a gendered division of labour, with men engaged in production work and women doing domestic work (see Murase, 2005).

After the Second World War, Home Economics education in Japan was influenced by the government's policies and ideals of gendered citizenship and differentiated education. During the period of rapid economic growth from the late 1950s to the early 1970s, the number of full-time housewives increased. In high schools, Home Economics in Japan went from an elective subject to a compulsory subject for girls, starting in 1970. The 1994 Convention on the Elimination of All Forms of Discrimination Against Women, which Japan signed, became the driving force behind making Home Economics a co-educational subject for all students. According to Kano (2011), the years 1995 to 2005 may go down in history as a decade when 'gender' became one of the most visible and hotly contested terms in Japanese political discourse.

In Norway, the progressive emergence of the dual-earner model and the distancing of women from the home during 1970s feminist movements meant that both boys and girls could learn to participate on equal terms in family and domestic life. Continuing in the same direction, support for family policy and gender equality reached a peak with the election of what is known as the 'women's government' of 1986 under the leadership of Norway's first female prime minister. The subsequent 1987 issue of the school plan marked a pinnacle for Home Economics teaching in Norwegian public schools. Not only were the number of teaching hours increased, but the curriculum had been revised to establish a clear focus on the practical skills (diaper changing, food preparation and housekeeping skills, to name a few) necessary for the equal division of household labour. In 1987, the presence of gender equality as a curricular theme was also strengthened. Following this peak for gender equality in Home Economics education, practical domestic skills were progressively phased out and hours reduced, making it today the subject with the least amount of teaching hours. In addition, the decline of domestic skills and gender equality as a curricular theme can be traced to the broader shift towards more neoliberalist and individualistic thinking in public policy and to a perception that gender equality has been achieved.

\section{Home Economics education from 2000 onward}

Home Economics in Japan now encompasses a wide range of fields, including not only food, clothing and shelter but also learning about family and childcare; it moreover engages students in consumer and environmental education (Ito, 2019). Currently, it consists of three main subjects: Family 
and home life; food, clothing and housing; and consumer life and environment. It is intended as a practical, 'hands-on' subject that engages pupils in experiential learning to acquire not only knowledge but also skills and techniques. Since 1994, it has been a compulsory, co-educational subject in primary, lower secondary and upper secondary school while the required teaching hours for Home Economics have steadily decreased since 1947.

In Japan, Home Economics in high schools has also undergone significant changes. The 1994 revision of the national Courses of Study boosted the required hours considerably, making mandatory a four-credit course for boys and girls. However, in 2003, during the conservative backlash of that decade, an alternative format was introduced - a two-credit course called Basic Home Economics. According to a survey by Nonaka et al. (2015), $63 \%$ of high schools in the Tokyo metropolitan area have switched to this reduced version of the course. As a result, the number of full-time Home Economics teachers has also decreased, with many schools having only one full-time teacher. This decline in teacher numbers raises questions about the consequences of a weakened professional network and the implications that it has for curricular innovation, teamwork and experience-sharing among teachers.

In Norway, from 2006 onward, the subject has been more clearly contextualised in a health and healthy lifestyle perspective to meet the societal challenge of preventing obesity and diet-related chronic diseases like diabetes. Today, the subject area is therefore represented by a compulsory 'Mat og Helse' (Food and Health) course that is further broken down into three subject areas: Food and lifestyle, food and culture, and food and consumption.

It is helpful to situate the current Food and Health curriculum - which aims to establish a solid foundation for enhanced physical and mental health and social well-being and social equity - more broadly within the 2020 governmental school reform. In light of this new framework, Food and Health is designed to teach students that skills related to food and meal preparation are of great importance to mental, physical and social wellbeing, and that the promotion of healthy eating habits and knowledge about nutrition have the capacity to lower social inequalities with respect to health.

Food and Health therefore has an ambitious mandate within the Norwegian societal context, but numerous studies have shown that the subject's lack of prestige within the public-school system have led to uneven and substandard practices in schools (Vik et al., 2020). In a recent study, Vik et al. (2020, p. 53) showed that in spite of national requirements, only half of current Home Economics teachers in Norwegian lower secondary schools possess formal qualifications to teach the subject. More recently, Bottolfs (2020) has shown through empirical research that teachers with a high level of formal competency in Home Economics demonstrate 
significantly better teaching practices with respect to 'choice of dishes, study materials and [sufficient] focus on the student's health and the theme of obesity' (p. 191).

In contrast to Norway's focus on dietary health, Japanese Home Economics has retained a broader thematic focus. In elementary school, for example, Home Economics' goals include developing the ability to relate better to others. It is also overtly focused on cherishing the notion of 'Japaneseness,' whereby children are educated on the importance of Japanese lifestyle and culture with regards to food, clothing and housing. In junior high school, cooperation continues to be emphasised; students learn about issues and practices in family and community life. At the senior high school level, themes include social change and the promotion of a sustainable society, dietary education, cooperation between men and women to build a family, understanding of the role of parents and child-rearing support, understanding the elderly, lifestyle planning, consumerism and environmentally friendly lifestyles, and the inheritance of Japanese lifestyle and culture (Sato, 2021). Despite this rather comprehensive list of themes connected to contemporary society, there is little to no explicit mention of gender issues in the teaching plan. Self-reliance, however, appears to have become greatly valued in today's high school curriculum in Japan, just as it has in Norway - which makes sense given the introduction of individualistic, neoliberal values into curricular thinking and rationales.

On the matter of gender equality in Japan, much attention has been paid in recent years to the question of whether the introduction of co-education in Home Economics in 1994 has brought about any significant changes in the attitudes and behaviour of women and men. Concerning women, a survey of 502 employed mothers in 2014 found that Home Economics courses influenced their ability to plan for the future and enhanced their sense of life fulfilment (Sano, 2016). Men who studied Home Economics in its co-educational form since it began in 1994 are now part of the childrearing generation. Compared to men who studied before 1994, their views on family and gender roles point in a revolutionary and gender-free ${ }^{1}$ direction (Nakanishi, 2011). Ishii-Kuntz (2013) has argued that the recent 'Ikumen phenomenon' in Japan - the rise of so-called 'good-looking' men who actively participate in raising children - has been closely linked to Home Economics education. Overall, Home Economics education has clear contribution to make in reducing Japan's gendered division of labour and in promoting men's behaviour in housework and childcare.

\section{Current teachers' perspectives on Home Economics}

In this section, we present the results of our qualitative study of teachers' perspectives on the relationship of Home Economics education to gender equality. Interviewees were asked about the following: Their motivation for working in the field, what they believe is unique about the subject of Home 
Table 5.1 Breakdown of Interviewees by Name, Country, Age and Current Position

\begin{tabular}{|c|c|c|c|c|}
\hline Name & Sex & Age & Affiliation & $\begin{array}{l}\text { Current } \\
\text { position }\end{array}$ \\
\hline Mika (Japan) & $\mathrm{F}$ & $50 \mathrm{~s}$ & $\begin{array}{l}\text { National university, Advanced } \\
\text { Practice of School Education }\end{array}$ & $\begin{array}{l}\text { Associate } \\
\text { Professor }\end{array}$ \\
\hline Yumi (Japan) & $\mathrm{F}$ & $40 \mathrm{~s}$ & Public high school & $\begin{array}{l}\text { High school } \\
\text { teacher }\end{array}$ \\
\hline $\begin{array}{l}\text { Mariko } \\
\text { (Japan) }\end{array}$ & $\mathrm{F}$ & $50 \mathrm{~s}$ & $\begin{array}{l}\text { National university, Family Studies } \\
\text { Pedagogy, Department of Life } \\
\text { Sciences, Faculty of Education } \\
\text { and Science }\end{array}$ & $\begin{array}{l}\text { Associate } \\
\text { Professor }\end{array}$ \\
\hline Emi (Japan) & $\mathrm{F}$ & $50 \mathrm{~s}$ & $\begin{array}{l}\text { National university, Graduate } \\
\text { School of Education }\end{array}$ & Professor \\
\hline $\begin{array}{l}\text { Marit } \\
\text { (Norway) }\end{array}$ & $\mathrm{F}$ & $40 s$ & Public lower secondary school & $\begin{array}{l}\text { Middle school } \\
\text { teacher }\end{array}$ \\
\hline $\begin{array}{l}\text { Lisbeth } \\
\text { (Norway) }\end{array}$ & $\mathrm{F}$ & $50 \mathrm{~s}$ & $\begin{array}{l}\text { National university, Department of } \\
\text { Teacher Training }\end{array}$ & Senior lecturer \\
\hline $\begin{array}{l}\text { Solveig } \\
\text { (Norway) }\end{array}$ & $\mathrm{F}$ & $50 \mathrm{~s}$ & $\begin{array}{l}\text { National university, Department of } \\
\text { Teacher Training }\end{array}$ & Senior lecturer \\
\hline $\begin{array}{l}\text { Gunhild } \\
\text { (Norway) }\end{array}$ & $\mathrm{F}$ & $40 \mathrm{~s}$ & Public lower secondary school & $\begin{array}{l}\text { Middle school } \\
\text { teacher }\end{array}$ \\
\hline
\end{tabular}

Economics in terms of academic content, the ways in which they approach teaching, salient differences (including gender) in the classroom, how they would like to see the subject evolve in the future, and the ways (if any) in which the curriculum and/or teaching approaches integrate the concept of 'gender equality.' The data was collected over a three-month period, from October to December 2020, in the form of semi-structured interviews. The survey participants were recruited in a snowball style from our initial contacts. The interview duration was one to two hours. Interviews in Norway were conducted in English and interviews in Japan were conducted in Japanese. A total of five university-level educators in Home Economics at national universities and three high or middle school-level Home Economics teachers were interviewed (see Table 5.1).

All of the university faculty members are principal members of the Japanese Society for Home Economics Education ${ }^{2}$ and have published Home Economics textbooks. As university faculty, Mika, Mariko and Emi are quite passionate and proactive, and while they can be considered leaders in the field of Home Economics education, they may not provide a representative picture of Home Economics teachers across Japan whose motivations and professional qualifications may differ. On the Norwegian side, it proved difficult to contact formally educated Home Economics teachers, given that roughly half of teachers in Home Economics in Norwegian lower secondary school do not have any formal education in the field and not all teacher training programs offer such a specialisation. Two 
university-level educators in Home Economics, Lisbeth and Solveig, were recruited from a prominent teacher training program in southern Norway offering a Home Economics specialisation. At the lower secondary level, we reached out to three schools in the Sør-Trøndelag region and recruited two teachers currently teaching in Home Economics: Gunhild has three to four years of experience in primary and lower secondary education, and Marit has over 15 years of experience in various primary and lower secondary schools in the region. As part of the data collection phase corresponded to the shift to online teaching due to pandemic-related school closures, all interviews took place online.

\section{Teachers' overall focus}

Much like the Japanese teachers, the Norwegian teachers report that there is no intentional or explicit focus on 'gender' or 'gender equality' in the school curriculum. It is assumed that all pupils participate equally in the cocreation of food and other practical exercises, irrespective of gender. When asked about how they approach the subject, their responses reflected a narrow focus on food preparation. The keywords that emerged from the interviews in Norway were 'creativity,' 'challenge' and 'diversity,' suggesting that experimentation and improvisation are important skills to free students from the idea that one mistake will ruin a recipe. Developing these attitudes takes priority over skill building. As Marit explained,

Everyone needs to be able to participate and feel the joy of cooking. I want my students to learn how to be independent. They can do this by learning and exploring their creativity. I don't want them to feel that cooking is rigid and that they are bound by rules.

Both current classroom teachers put great emphasis on the ways in which they perceived the practical subjects like Food and Health to be more inclusive and welcoming to diverse student abilities. According to Marit, 'Students should be able to read a recipe and collaborate in groups with the understanding that everyone has something to contribute....Creating a cosy environment is key; it opens up something different than the theoretical subjects. Discovery is important.' Similarly, in Japan, Yumi explained, 'I choose assignments that can be completed in a short period of time and value the students' sense of accomplishment. In Home Economics, kids who don't stand out in other subjects can show their individuality.'

In Japan, in 1947, after the Second World War, the topics covered in Home Economics were not limited to food and nutrition, but shifted from sewing to democratic family relations, and now include a wide range of topics such as food, housing, childcare, consumer education, environmental issues and even financial education. The interviews with teachers suggest that the goal of Home Economics in Japan is for students to acquire 
knowledge and skills to support self-reliance. Equally, they should develop the ability and desire to understand the function of the family and to improve their lives. Mika explained,

I want students to be aware of everything and learn new things. I want them to be able to do things if they try, and to value a sense of accomplishment. I want them to have life skills and to have a perspective on their life stages.

\section{Gender equality as an implicit value}

Both Japanese and Norwegian teachers claim at first that they do not consciously teach about gender-related issues in her classroom, nor do they perceive any gendered division of labour in the practical tasks. Norwegian classroom teachers reported no gender-related differences in skill level among their students. They did, however, point to differences related to the level of home support, pointing out that socio-economic factors influencing the home may play a more significant role than a student's gender: 'For some students [cooking activities] give them a greater chance to thrive and showcase their skills, for others [who have no chance to cook at home] it's like going to the moon' (Gunhild).

In Norway, Solveig shared the belief that the conceptualisation of Food and Health as an essential subject at the political level, which has an increasingly individualistic and neoliberalist approach, has contributed to a sidelining of gender equality and women's contributions to the field:

It's the politicians who obviously don't understand that Food and Health could be a foundation...for the new curriculum. They don't see it as connected to the interdisciplinary theme of 'democracy and citizenship', which is crazy because think of gender, for instance, which is so important in Food and Health. The pioneers of the field in the 19th century saw gender as a focus, and they even made Food and Health schools for boys in Sognefjord. Much of the aim of the subject was of course to level the differences in the society - that has a lot to do with democracy and citizenship, so it's a missed opportunity.

The transition to Food and Health from the 1980s focus on domestic tasks and gender equality reflects the view that newly emerging societal problems such as obesity should take priority because gender equality has already been achieve in Norway. Solveig sees the potential contribution of Food and Health in a broader perspective regarding the role it can play in reducing social inequality overall.

For their part, Japanese interviewees claim that male students participate in the class without any tangible sense of discomfort. However, in 
conversations between students during class, Yumi sometimes sees them making value judgments based on gender, such as, 'It's strange that you're a girl and you're not good at Home Economics,' or 'It's amazing that you're a boy and you're good at sewing.' In schools, there is a tendency to emphasise theoretical subjects related to university entrance examinations, and therefore home economics classes that involve practical skills are neglected. She also feels that the content of the classes, with the recent reductions in required hours and the resulting time constraints, have rendered the classes broad and shallow, making it difficult for students to learn skills such as cooking and sewing in a meaningful way.

Mariko, associate professor at another university that also trains Home Economics teachers, also responded that she herself does not talk about gender equality emphatically to her students. One of the classes she teaches is called 'Research on Teaching Materials,' in which student teachers freely choose teaching materials and present them during seminars. Mariko has noticed a recent increase in the students who choose 'gender equality' as their theme. She worries that university students are interested in marriage couples working together to do housework and childcare in their own lives but they are unable to develop teaching materials where they can actually try their hands at it. In fact, she has little experience in teaching with hands-on teaching materials. Many classes end with writing on a printout or reading a textbook. Home economics classes need to have a balance between 'theory and practice,' she said.

According to the response of the students in Emi's college class and feedback from in-class discussions, most male students would like to take childcare leave in the future. However, when asked who will cook the meals and clean the house during the period of leave, few of these male students answered that they will do it themselves. Rather, they assumed their future wives will do it. In response, Emi stated that it is essential for everyone to learn domestic skills in Home Economics classes.

\section{No more washing temperatures, no more ironing: A home life built on creativity}

When asked about the absence of skills related to housework and other domestic tasks in the current Food and Health curriculum, the university educators in Norway were not entirely in agreement. Lisbeth expressed a sense of relief that the subject no longer addresses domestic tasks such as laundry and ironing:

I'm glad that [Home Economics] doesn't include learning about these kinds of tasks anymore. In the past, there was nothing in the curriculum about gender equality in the kitchen because there was no gender equality. It was more about how to iron your tablecloth and how to divide different clothes to different washing temperatures. I'm happy 
that that's out. That should be taught in homes so that in school we are free to focus on something else. The household division of household labour in the home fits more in the social sciences than my view of Home Economics as a topic.

For Lisbeth, domestic tasks reflect an outdated image of the subject, reflecting a time when Home Economics played a role in locating women's work in the home and, in her view, was associated with the carrying out of very unimaginative tasks. Lisbeth expresses a sense that the subject today should be more open and concerned with building a life based on independence and creativity. Regarding her student teachers in Food and Health, she reports,

I want for them to feel so secure in their skills, the specific cooking skills, but also the didactics, so that they can also leave the control to students and let them be creative. Because it seems now that by the time we get our student teachers into their third year of teacher education, we have somehow 'uncreativitied' them. When they are finally able to think outside the box, that that's when the fun starts and that's when the magic happens. It's not just about replicating some oppskrift [recipe] or doing something the way we always did. That's not how to build a life.

From this perspective, Lisbeth wants to promote the idea that a home life shared together is less about the carrying out of uninventive, uninspiring tasks than it is about innovation and creativity. In her view, taking an academic approach to the household division of labour would be more fitting to the social sciences. Solveig on the other hand perceived the omission of domestic skills as an unfortunate legacy of feminism's endeavour to liberate women from the home. This suggests a tension in Home Economics in Norway between teachers who wish to focus on skills and those emphasising attitude development.

\section{Domestic skills for a fulfilling life}

Both concerns - skills and attitude development - emerged in the Japanese interviews, too. The keywords that emerged from the Japanese educators' interviews are 'housework skills' and 'sense of accomplishment.' The student teachers expressed that they wanted both boys and girls to learn housekeeping skills and to have a sense of accomplishment that they could do this if they tried. For example, Emi states,

I see value in raising children well, building strong marital relationships, balancing professional and family life, and this can be achieved through domestic skills. No matter how many ideas of gender equality 


\section{Jennifer Branlat and Junko Sano}

and caring and kind words we have, it will be completely meaningless without domestic work skills. It is very important for both men and women to have the ability to live independently. I have the impression that Home Economics is divided into two areas, one dealing with human relations and the other with things.

Achieving gender equality in Japan will require individual independence, and consumer, environmental and financial education: Critical knowledge about food, clothing and housing is essential. Although the subjects of this survey responded that they did not pay special attention to gender equality in their classes, they spoke of their intention to not pursue gender equality actively in their classrooms but rather to help all students acquire the life skills required to realise a gender-equal society.

\section{Discussion}

In both Norway and Japan, the challenges associated with the field of Home Economics as described in the research literature came up in the interviews with teachers. They identified tangible roadblocks that prevent them from accomplishing the curricular objectives. In particular, in Norway, the reduced number of hours, lean budget and low status of Food and Health as an academic topic perpetuate attitudes that the subject is less important than theoretical subjects. Further, the idea that learning about domestic tasks and the equal sharing of household work should take place in the private sphere - and not take up valuable space in the school curriculum - was suggested as one of the benefits of the relatively new focus on Food and Health. The Japanese case is similar. Although Home Economics has been recognised as fundamental to developing individual independence, gender equity, collaborative ability and life skills, it too has experienced diminished support in terms of hours, budget and prestige. Many high schools have only one full-time teacher, who is eventually replaced by a part-time teacher. In addition, in both countries, a high percentage of Home Economics teachers are women, and the percentage of students studying Home Economics education at universities is also overwhelmingly female. This trend has not improved to date. The image that Home Economics in Japan is an activity for women has not been completely eradicated.

The most significant difference between Norway and Japan in Home Economics education today concerns the place allocated to the learning of domestic skills in the curriculum. With the focus narrowed to Food and Health following public health concerns over obesity, domestic skills in Norway are today absent from the school curriculum and relegated to the private sphere. In Japan, domestic skills still form an important part of the curriculum. They are based on the idea that such skills make, in the words of one teacher, 'raising children well, building strong marital relationships [and] balancing professional and family life' more possible. However, like 
Japanese teachers, Norwegian educators expressed ideals of a home life based on freedom, creativity and the cultivation of joy in food preparation. The trained Home Economics educators in higher education were divided on the absence of domestic skills in the current curriculum. Some of the interviewees viewed domestic skills rather negatively, associating them with the housewife era and an outdated image of women's work. Others lamented the loss of these skills that potentially reduce social inequalities. In the words of Solveig, 'How can we assume that such skills can be acquired at home when we don't assume the same for other subjects? Why should domestic skills be an exception?'

Today the notion of gender equality in Norway, one of the so-called 'model' countries for work-life balance and gender equality, is covered only theoretically in the social studies curriculum in spite of persisting inequalities within the home concerning the sharing of domestic tasks. We might ask for future research, what is lost when students approach gender equality in theoretical terms (e.g., in social studies) and fail to gain the embodied knowledge provided by the development of hands-on skills? Our study also supports the literature on the current challenges facing the subject by introducing teachers' lived experiences with such difficulties.

While the curricular content of Home Economics in Japan has become increasingly broadened, Norway has chosen to narrow its focus to food and health. Domestic skills and family care, which figured most prominently in the curriculum during the mid-1980s, have been phased out. This may be due to a prevailing cultural attitude that these skills are best cultivated within the space of the home, but more research on Norwegian attitudes towards domestic work is needed to complement the body of literature on time sharing within the home.

Although similar cultural attitudes may be in play in Japan, there is a movement to rethink housework in a 'modern' way, as represented in the KonMari Method ${ }^{3}$ by Marie Kondo whereby rooms are cleaned and organised in creative and meaningful ways. Our interviews with Home Economics educators in Norway suggest that, much like their Japanese counterparts, they embrace the development of creativity and ingenuity as valuable assets in the curriculum, but their potential impact on the home has been limited due to the subject's instrumental turn toward Food and Health in the 2000s and by negative cultural attitudes concerning domestic tasks due to their association with the housewife era in Norway when women's workplace primarily limited to the home. We believe that Norway can learn from the idea that daily housework and domestic tasks may provide an outlet for creative thinking. Developing a more positive association with such activities can help students to lead more fulfilled lives.

On the other hand, Japanese Home Economics may have a good deal to learn from the Norwegian context. According to Furuichi (2019), gender equality in Norway did not start with an ideology. As the expansion of the welfare state in the 1960 s led to a shortage of labour and rising prices, it 


\section{Jennifer Branlat and Junko Sano}

became difficult for a single man to make a living, which in turn led to the participation of women in the workforce. Japan is currently experiencing a labour shortage due to the declining birth rate and ageing population, putting it in much the same situation as Norway 60 years ago. Japan also needs to learn from Norway's policies, social welfare system and awareness of gender equality.

Finally, in both countries, Home Economics should be given a more prominent and prestigious place in the overall curriculum as societies around the world seek out more sustainable and ecological ways of living both at the household and societal levels. Research and practice should be used to show how environmentally friendly and gender-equal home management can contribute to society in the future, and adequate class time should be reserved for this.

\section{Notes}

1 'Gender free' is a Japanese term meaning free from the imposition of historical, cultural and social gender differences. But this term also incited right-wing backlash in Japan.

2 Landslaget for mat og helse i skolen (LMHS) is one of the Norwegian equivalents.

3 The KonMari Method (2021) encourages tidying by category - not by location beginning with clothes, then moving on to books, papers, komono (miscellaneous items), and, finally, sentimental items. Keep only those things that speak to the heart, and discard items that no longer spark joy.

\section{References}

Bleazby, J. (2015). Why some school subjects have a higher status than others: The epistemology of the traditional curriculum hierarchy. Oxford Review of Education, 41(5), 671-689.

Bottolfs, M. (2020). Mat og helsefaget i dagens skole [Food and health studies in today's school]. Norsk Pedagogisk Tidsskrift, 2, 181-193.

Cousins, C., \& Tang, N. (2004). Working time and work and family conflict in the Netherlands, Sweden and the UK. Work, Employment and Society, 18(3), 531-549.

Ellingsæter, A.L. (2009). Leave policy in the Nordic welfare states: A 'recipe' for high employment/high fertility? Community, Work and Family, 12(1), 1-19.

Furuichi, K. (2019). Norway niokeru ikujiseisaku to danjobyoudou no toutatasutenn:nihon tono hikaku, Kita yo-roppa kennkyuu. Japanese Journal of Northern European studies, 15, 1-11.

Gender Equality Bureau, Cabinet Office, Government of Japan. (2020). Balancing work and housework/childcare/caregiving: how do individuals, households, and society face the issue? https://www.gender.go.jp/english_contents/about_danjo/ whitepaper/index.html.

Hook, J.L. (2010). Gender inequality in the welfare state: Sex segregation in housework, 1965-2003. American Journal of Sociology, 115(5), 1480-1523.

Ishii-Kuntz, M. (2013). 'Ikumen' gennshou no shakaigaku [Sociology of child caring men]. Minerva Shobo. 
Ito, Y. (2019). Series kennkyu no doukou kateikyouiku no doukou [Trends in research series]. Nihon kasei gakkaishi [The Japan Society of Home Economics], 70(12). https://doi.org/10.11428/jhej.70.845

Kano, A. (2011). Backlash, fight back, and back-pedaling. International Journal of Asian Studies, 8(1), 41-62.

Kitterød, R.H., \& Rønsen, M. (2012). Non-traditional dual earners in Norway: When does she work at least as much as he? Work, Employment \& Society, 26(4), 657-675.

Kondo, M. (2021). KonMari Method: Fundamentals of tidying up. KonMari Media, Inc. [Trademark]. https://konmari.com/

Kondo, M. (2014). The life-changing magic of tidying: A simple, effective way to banish clutter forever. Ebury Publishing.

Koyama, S. (2014). Domestic roles and the incorporation of women into the nationstate: The emergence and development of the 'good wife, wise mother' ideology. In A. Germer (Ed.), Gender, nation and state in modern Japan, 85-100. Routledge.

Larsen, E. \& Hagemann, G. (2011). Husmorens foranderlighet [The housewife's changeability]. Tidskrift for Kjønnsforskning [Journal for Gender Research], 34, 267-273.

Makino, K. (2005). Kateika no kako genzai mirai [The past, present and future of Home Economics]. Kateikakyouiku [Home Economics Education], 79, 6-11.

Melby, K. (1989). The housewife ideology in Norway between the two World Wars. Scandinavian Journal of History, 14(3), 181-193.

Murase, M. (2005). Kateika to gender [Home Economics and gender]. Doushisha jyoshi daigaku sougou bunka kennkyuusho kiyou [Bulletin of Institute for Interdisciplinary Studies of Culture, Doshisha Women's College of Liberal Arts], 22, 33-44.

Nakanishi, Y. (2011). Dannjyo kyoutsuu hissyuu kateika no seika to kadai [Effects and issues of coeducational Home Economics]. Nibon kateika kyouiku gakkaishi [Japan Association of Home Economics Education], 53(4), 217-225.

Nonaka, M., Kamei,Y., Shinyama, M., Arai, K., Arai, T., Ishijima, E., Niyama, M., Sanada, C., \& Taklahashi, R. (2015). Koukou kateika dannjyo hisyuugo 20nen no risyuu kannkyou no kennshou [Learning environment of co-educational Home Economics in senior high schools for 20 Years: Through curriculum investigation in 4 prefectures in Kanto District]. Nihon kateika kyouiku gakkaishi [Japan Association of Home Economics Education], 58(2), 79-89.

Øvrebø, E.M., \& Engeset, D. (2020). Fagdidaktikk $i$ mat og helse (2nd ed.). Cappelen Damm akademisk.

Sano, J. (2016). Kateika no manabi no ninnshiki to jyosei no syuurou to seikatsu manzokukann [The Effect of Home Economics on Women's Work-Styles and Life Fulfillment: A Comparison of before and after coeducational home economics education]. Nihon kateika kyouiku gakkaishi [Japan Association of Home Economics Education], 59(1), 24-34.

Sato, Y. (2021). Kateikakyouiku ni okeru kajiroudou no atukai to sono benyou -Shakaiteki kadai ya seisaku no doukou nichakumoku site-[Treatment of housework in Home Economics education: Relationship with social issues and the government policies]. Nihon kateika kyouiku gakkaishi [Japan Association of Home Economics Education], 63(4), 191-202. 


\section{Jennifer Branlat and Junko Sano}

Seierstad, C., \& Kirton, G. (2015). Having it all? Women in high commitment careers and work-life balance in Norway. Gender, Work \& Organization, 22(4), 390-404.

United Nations General Assembly. (2015, 21 October). Transforming our world: The 2030 agenda for sustainable development (A/RES/70/1). [Report]. https:// www.refworld.org/docid/57b6e3e44.html

Vik, F.N., Beinert, C., Palojoki, P., Hillesund, E.R., Engeset, D., Ask, A.S., Åbacka, G., \& Øverby, N.C. (2020). Differences in formal education among Norwegian Home Economics teachers. Journal of the International Society for Teacher Education, 24(2), 45-59. 